Fall 1991

\title{
Dēmētrios S. Inglezēs: Greek Merchant and City Leader of Odessa
}

Theophilus C. Prousis

University of North Florida, tprousis@unf.edu

Follow this and additional works at: https://digitalcommons.unf.edu/ahis_facpub

Part of the History Commons

\section{Recommended Citation}

Prousis, Theophilus C., "Dēmētrios S. Inglezēs: Greek Merchant and City Leader of Odessa" (1991). History Faculty Publications. 6.

https://digitalcommons.unf.edu/ahis_facpub/6

This Article is brought to you for free and open access by the Department of History at UNF Digital Commons. It has been accepted for inclusion in History Faculty Publications by an authorized administrator of UNF Digital Commons. For more information, please contact Digital Projects.

(C) Fall 1991 All Rights Reserved

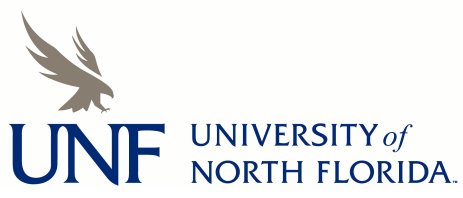




\section{THEOPHILUS C. PROUSIS}

\section{Dēmētrios S. Inglezēs: Greek Merchant and City Leader of Odessa}

Greek merchant settlement of the northern coast of the Black Sea extends back to classical and Byzantine times. After the founding of Odessa in 1794, Greek and other foreign merchants played a major role in transforming this provincial backwater into one of the leading grain emporiums of Europe, a cosmopolitan city of ethnic diversity and cultural vitality. Dēmētrios Spyridonovich Inglezēs (1773-1844) is a concrete example of the prosperous Greek trader who assimilated to his new environment and engaged in numerous civic endeavors promoting the commercial and urban growth of Odessa during its formative decades. He also retained a sense of Greek identity and participated in the Russian philhellenic movement during the Greek revolt of the 1820s. The experience of this prominent merchant typified that of other successful Greek traders in Odessa and contributes to recent scholarship on that city's Greek community and on the broader theme of historical connections and contacts between Russia and the Greek east in the post-Byzantine era. ${ }^{1}$

Dēmētrios S. Inglezēs, born on the Ionian island of Cephalonia in 1773, came from an old noble family included among the aristocratic families enrolled in the Cephalonian golden book. For more than three centuries, the Inglezēs family had produced members who were educated,

The research for this article was made possible by the support of the International Research and Exchanges Board (IREX) and by the assistance of the archival staff at the state archive of Odessa oblast (GAOO).

1. See Patricia Herlihy, "The Ethnic Composition of the City of Odessa in the Nineteenth Century," Harvard Ukrainian Studies 1 (1977):53-78; idem, "Greek Merchants in Odessa in the Nineteenth Century," Harvard Ukrainian Studies 3-4 (1979-1980):399-420; and idem, "The Greek Community in Odessa, 1861-1917," Journal of Modern Greek Studies 7 (1989): 235-252. Herlihy's work on the Greek community is included in her Odessa: A History, 1794-1914, Harvard Ukrainian Research Institute Monograph Series (Cambridge: Harvard University Press, 1986). The most prominent Soviet historian dealing with Greek-Slavic relations, specifically with Greek national independence and Russia, is Grigorii L. Arsh. His works Eteristskoe dvizhenie $v$ Rossii. Osvoboditel'naia bor'ba grecheskogo naroda $v$ nachale XIX $v$. $i$ russko-grecheskie sviazi (Moscow: Nauka, 1970) and I. Kapodistriia i grecheskoe natsional'no-osvoboditel'noe dvizhenie, 1809-1822 gg. (Moscow: Nauka, 1976) are solidly grounded in archival sources. Arsh has also published several articles on Greek-Slavic themes in Balkanskie issledovaniia. For a review of the contributions by Arsh and other Soviet neohellenists to the first ten volumes of Balkanskie issledovaniia (1974-1987) see Constantine C. Papoulidis, "Themes of Modern Greek History in Recent Soviet Publications on Balkan Studies," Modern Greek Studies Yearbook 3 (1987):273-281. The first six volumes of Modern Greek Studies Yearbook (1985-1990) contain several additional articles on specific aspects of Greek-Slavic cultural relations.

This article is based almost entirely on Inglezēs's personal archive, in the state archive of Odessa oblast. The fond contains fifteen dela, ranging from two to seven pages except for his formuliarnvi spisok, a thirty-three page document constituting the best single source on Inglezēs. GAOO, fond 268, opis' 1, dela 1-15. The formuliarnyi spisok is in delo 2. Unless otherwise indicated, all subsequent references to GAOO are from this fond and opis'.

The information in the fond has dictated that this research focus on the public rather than the private life of Inglezēs. While described as a lichnyi fond, it contains precious little on his family, household, residence, merchant firm, and other personal matters that would lend a more human dimension to this portrait of Inglezēs. Even some of his civic endeavors are not described in sufficient detail, thus imparting a sense of incompleteness to this discussion of his activities. Despite these constraints, the fond does contain enough information to suggest the extent of his assimilation and wide-ranging public service. Further investigation of municipal records will probably unearth additional material on his public and, perhaps, his private life, thereby allowing a more well-rounded profile of Inglezēs.

Slavic Review 50, no. 3 (Fall 1991) 
active in trade, and "diligent and unselfish in important civic positions entrusted to them," a family tradition Dēmētrios Spyridonovich would continue in southern Russia. ${ }^{2}$

Inglezēs's early years are shrouded in uncertainty. With the death of his father in 1787 , the fifteen-year-old Dēmētrios and his uncle left Cephalonia and worked as shippers at Taganrog, a naval and commercial port on the Sea of Azov with a sizable Greek population. The two volunteered their services to the Russian navy in the Russo-Turkish War of 1787-1792, during which Inglezēs participated in four Black Sea campaigns and was promoted from ensign to captain. For reasons that are unclear, Inglezēs attempted to return to Cephalonia after his naval stint. The journey home was a disaster, with Inglezēs barely surviving a storm that destroyed the ship's cargo and his family papers. The exact date of Inglezēs's arrival in Odessa is unknown. In 1805, however, Armand-Emmanuel du Plessis, Duc de Richelieu, the governor-general of Novorossiia whose enlightened administration stimulated Odessa's growth, called on Inglezēs to hire commercial vessels to ship supplies to Russian forces on the Russian-protected Ionian islands. Inglezēs, using his own capital, fulfilled this task to the satisfaction of Richelieu. ${ }^{3}$

Inglezēs's settlement in Odessa was part of the large wave of Greek migration to southern Russia in the late eighteenth and early nineteenth centuries. Greek and other foreign settlers were drawn by tsarist incentives, including exemptions from taxes and service. The commercial potential of Odessa and other ports beckoned to enterprising Greek traders and shippers, and they soon became the backbone of Russia's emerging merchant fleet in the Black Sea. Russo-Ottoman commercial agreements also permitted Greek subjects of the sultan to fly the Russian flag on Greek vessels. These factors stimulated Russian commerce in the Mediterranean and the growth of a Greek merchant marine that reaped lucrative profits during the Napoleonic era. ${ }^{4}$

Greek commercial success in Odessa's burgeoning grain trade has been well documented in several studies. ${ }^{5}$ Inglezēs participated in this commerical upsurge, becoming one of the city's most prosperous and respected merchants. By 1817 his firm was one of the ten wealthiest Greek companies in Odessa; the net worth of the ten firms together was about ten million rubles. ${ }^{6}$ In 1847, three years after his death, the Inglezēs firm was considered one of the leading companies in the Russian Empire. Further investigation of custom registry records and other commercial documents may reveal more specific information on the organization, activity, and profits of his firm, his ties with western trading houses, and his standing in a stratified Odessan Greek society. In view of his success, his company clearly took advantage of Odessa's strategic location on a

2. GAOO, f. 268 , op.1, d. 1 "Dokumenty o proiskhozhdenii roda Inglezi iz dvorian Venetsianskoi respubliki," 1. 1-7a.

3. Ibid., d. 2, 1. 1-8. On the storm see Inglezēs's nekrolog, or obituary, in Odesskii vestnik, no. 4 (22 May 1846): 203-204 (hereafter cited as nekrolog). See Herlihy, Odessa, 21-48, on the effect of Richelieu's policies on municipal development. A. M. Stanislavskaia discusses Russia's Ionian protectorate in Rossiia i Gretsiia. Politika Rossii v Ionicheskoi respublike, 1798-1807 gg. (Moscow, 1983).

4. Roger Bartlett, Human Capital: The Settlement of Foreigners in Russia, 1762-1804 (Cambridge: Cambridge University Press, 1979), provides a general picture of foreign settlement in Novorossiia. On Greek migration see G. M. Piatigorskii, "Grecheskie pereselentsy v Odesse v kontse XVIII-pervoi treti XIX v.," in Iz istorii iazyka i kul'tury stran Tsentral'noi i Iugo-Vostochnoi Evropy, ed. V. N. Vinogradov (Moscow: Nauka, 1985), 33-60; G. L. Arsh, "Grecheskaia emigratsiia v Rossiiu v kontse XVIII-nachale XIX v.," Sovetskaia etnografiia, no. 3 (1969):85-95; and Nicholas C. Pappas, "Greeks in Russian Military Service in the Late Eighteenth and Early Nineteenth Centuries" (Ph.D. diss., Stanford University, 1982). On the merchant marine see George Leon, "The Greek Merchant Marine (1453-1850)," in The Greek Merchant Marine, ed. S. A. Papadopoulos (Athens, 1972), 32-43. On the expansion of Greek trade activity see Traian Stoianovich, "The Conquering Balkan Orthodox Merchant," Journal of Economic History 20 (1960): 234-313.

5. In addition to Herlihy's works, see V. Karidis, "A Greek Mercantile paroikia: Odessa, 1774-1829," in Balkan Society in the Age of Greek Independence, ed. Richard Clogg (Totowa, N.J.: Barnes and Noble, 1981), 111-136, and J. Nicolopoulos, "Correspondence commerciale d'Odessa: Quelques renseignements sur l'activité des Grecs en Russie méridionale en XIX siècle," Eranistēs 17 (1983):224-235.

6. Logios Ermès, no. 1 (January 1817): 13-14. 
commercial nexus linking the Black Sea to the archipelago and the Mediterranean, a diaspora network benefiting from frequent contacts with business partners and compatriots. ${ }^{7}$

Inglezēs made Odessa his permanent home, finding and helping to build a conducive environment for a successful and productive life. Commercial prosperity facilitated assimilation as did his Eastern Orthodox faith and his marriage to Ekaterina Zoeva Kutsovskaia, the daughter of a Russian noble. They had five children, and Inglezēs family members still resided in Odessa in the early twentieth century. ${ }^{8}$ Inglezēs's assimilation is indicated by his broad range of civic activity, which earned him a reputation for honesty, resourcefulness, and conscientiousness. ${ }^{9}$

Successful merchants were often called upon by local authorities to participate in municipal affairs. Inglezēs served on numerous committees, including the commercial court that handled trade disputes and committees on construction, the status of Odessa as a free port, quarantine and customs facilities, and municipal revenues and expenditures. ${ }^{10}$ Although the Inglezēs archive provides few details on his duties and tasks, Inglezēs's involvement in municipal governance did shape the city's urban and commercial development, which in turn contributed to the continued success of his firm.

Inglezēs's wide-ranging civic spirit supported numerous endeavors indicative of his integration into Russian and Odessan society. During the Napoleonic campaign of 1812, he was appointed by local authorities to collect donations from fellow Greeks for Russia's defense. Under his direction and with sizable contributions from other wealthy merchants like Theodōros Seraphinos and Grēgorios Marazlēs, the Greek community donated one hundred thousand rubles, more than any other ethnic group in Odessa. Inglezēs also collected donations from local Greeks for the construction of a hospital and an Orthodox church. In 1815 correspondence the hospital commission expressed gratitude for his efforts to raise twelve thousand rubles for this benevolent project and announced its intent to commemorate Inglezēs and other contributors on a marble plaque near the building. ${ }^{11}$

Odessa confronted several outbreaks of plague because of its regular traffic with endemic centers of the disease in the Near East. During the 1812-1813 plague epidemic, GovernorGeneral Richelieu divided the city into five sections, each with its own inspector and doctor who could impose a quarantine. Inglezēs was an inspector and organized the supply of food and other essentials to the poor in his section. He performed his assignment diligently, often using his own money for emergency aid. ${ }^{12}$

Inglezēs's public service included a brief stint as mayor from 1818 to 1821 , an appointment based on his growing reputation for honesty and industriousness in municipal affairs. His tenure

7. Herlihy, "Greek Merchants in Odessa," 401, 407-412. The merchant firm of the Rallis family, one of the largest companies in Odessa, had branch offices in Constantinople, Marseilles, London, and Manchester. Western travelers, like Henry Holland in Travels in the Ionians, Albania, Thessaly, and Macedonia (London, 1815), 148-150, often noted the family and business networks linking Greek merchants in Europe, Russia, and the Greek world.

8. GAOO, d. 2, 1. 1-8. Herlihy, "Greek Merchants in Odessa," 418, notes that several members of the Inglezēs family were included in the Odessa city directory for 1910 .

9. Nekrolog, 203-204.

10. GAOO, d. 2, 1. 1-7, and d. 3, "Uchastie v komitete o dokhodakh i raskhodakh Odessy," 1. 1-7. Inglezès was not the first Ionian Greek to participate in municipal governance. The merchant Ivan P. Destunis served as burgomaster on the Odessan town council from 1797 to 1800 , earning the praise of government authorities, including Tsar Paul I, for his successful discharge of duty and his contribution to the wellbeing of the new town. See Theophilus C. Prousis, "The Destunis Collection in the Manuscript Section of the Saltykov-Shchedrin State Public Library in Leningrad," Modern Greek Studies Yearbook 5 (1989): 407-408.

11. GAOO, d. 3, "Kvitansiia o poluchennykh pozhertvovaniiakh na opolchenii," 1 . 1, and G. M. Piatigorskii, "Grecheskie pereselentsy v Odesse," 51. GAOO, d. 13, "O pozhertvovanii v pol'zu Odesskogo gospitalia grecheskimi kuptsami," 1. 1-2.

12. Nekrolog, 203-204. See Herlihy, Odessa, 45-46, 132-133, 234-235, on plague and cholera epidemics in Odessa. 
was highlighted by the visit in 1818 of Tsar Alexander I who awarded Inglezēs the Order of St. Vladimir, Fourth Class, for his "earnestness and diligent service." ${ }^{13}$ The tsar acknowledged the rapid growth of the city his grandmother had founded and bestowed upon it forty thousand rubles for public works projects, including an aqueduct and street paving. ${ }^{14}$ The tsar thus tried to address two key problems plaguing urban life in Odessa, the lack of adequate fresh water and the absence of paved streets. Despite tsarist concern, municipal officials were unable to resolve these issues until the late nineteenth century.

Inglezēs also retained his sense of Greek identity. Greek settlers formed compact neighborhoods in the center of town with a Greek street and a Greek bazaar. Regular commercial traffic in the Mediterranean allowed Odessan merchants to maintain their ties with relatives and compatriots. Above all, the Greeks of Odessa preserved and cultivated their faith, language, and cultural heritage, as did the Greek communities of Moscow, St. Petersburg, and western and Central Europe. Greek merchant wealth and Russian patronage helped stimulate a Greek intellectual awakening commonly known as the neohellenic enlightenment. ${ }^{15}$

Inglezēs contributed to Greek learning primarily through his association with the Greek commercial gymnasium of Odessa, one of several local educational institutions in his record of public service. Several Greek merchants, including Inglezēs, founded the school in 1817 and organized its administration and curriculum. The gymnasium, whose teachers were mostly Greek, taught courses in commerce and navigation; geography and world history; ancient and modern Greek, Russian, Italian, and German; religion; and natural sciences. By 1818 the school had about two hundred and fifty students from Russia and the Greek world, and its initial success as an educational institution was noted by Russian and Greek contemporaries. With a Greek theater founded in 1814, the school made Odessa a Greek cultural center. The city's location linking Russia, Europe, and the Greek east also made it a natural point for the exchange and circulation of Greek books published in Moscow, Venice, and Vienna. ${ }^{16}$

13. GAOO, d. 2, 1. 13-16, 1-8. Additional research in GAOO, especially the records of the city council, may further illuminate Inglezēs's term as mayor.

14. Herlihy, Odessa, 115.

15. For a general picture see Deno J. Geanokoplos, "The Diaspora Greeks: The Genesis of Modern Greek National Consciousness," in Hellenism and the First Greek War of Liberation (1821-1830): Continuity and Change, eds. Nikiforos Diamandouros et al. (Thessaloniki: Institute for Balkan Studies, 1976), 59-77. See Arsh, Eteristskoe dvizhenie v Rossii, 129-166, 200-222, on the retention of national consciousness in the Greek communities of Russia. É en Odëssö Ellēniki Ekklēsia tēs Agias Triadas, 18081908 (Odessa, 1908) provides a historical sketch of the Holy Trinity Greek Orthodox Church of Odessa, an institution that preserved Greek cultural tradition. On the Greek Enlightenment in Russia see the works of Arsh, Kapodistriia i grecheskoe natsional' no-osvoboditel' noe dvizhenie, 124-169; idem, "Novogrecheskoe Prosveshchenie i Rossiia, k postanovke probleme," Balkanskie issledovaniia 9 (1984):304-313; and idem, "Grecheskii uchenyi D. Gobdelas v Rossii," Balkanskie issledovaniia 6 (1980):161-173. The connection between diaspora merchants and Greek learning is illustrated by the Zösimas brothers of Moscow who sponsored the monumental edition of the Greek classics published in Paris by Adamantios Koraēs, the Greek educator and a leading figure in the Greek Enlightenment. See Phanēs Michalopoulos, Ta Giannina kai $\bar{e}$ neoellēnikè anagennēsè, 1648-1820 (Athens, 1930), 12-87.

16. GAOO, d. 4, "Uchastie v komissiiakh po proverke schetnykh del Rishel' evskogo litseia," 1. 1-3, and d. 5, "Uchastie v sovete Odesskogo devich'iago instituta," 1. 1-1a. On the school curriculum see Ch. Voulodēmos, Protē pentēkontaetēris tès en Odēssö Ellēno-emporikēs scholēs (1817-1867) (Odessa, 1871), 207-213. For a recent study of the school based on archival materials from the Ministry of Public Education see Arsh, "Grecheskoe kommercheskoe uchilishche Odessy v 1817-1830 gg. (Iz istorii novogrecheskogo Prosveshcheniia)," Balkanskie issledovaniia 10 (1987):31-61. On its reputation see "O grecheskom uchilishche v Odesse," Vestnik Evropy 110, no. 7 (1820):202-208, and Voulodēmos, Protē pentēkontaetēris, 108-110. On the Greek theater see G. Zoidēs, "To theatro tēs Philikēs Etaireias," in Ellēnismos eis to exōterikon, eds. J. Irmscher and M. Mineemi (Berlin, 1968), 397-436. The Section of Rare Books and Manuscripts in the Gor'kii Public Library in Odessa has numerous Greek texts representative of the Greek Enlightenment, including the three-volume Greek dictionary of Anthimos Gazēs published in Venice from 1809 to 1816. 
Inglezēs did not join the Philikē Etaireia, the conspiratorial society that was founded in Odessa in 1814 and hatched the Greek revolt. His noninvolvement in this revolutionary organization underscores his attachment to his new homeland and the stratification of Greek merchant society. The Etaireia, a product of economic anxiety, social dislocation, and embryonic national consciousness, attracted membership from a broad spectrum of diaspora and Ottoman Greeks, with merchants making up the single largest group (53.7 percent). Most of these merchants, typified by the Etaireia's three founders, consisted of small-time traders adversely affected by declining grain prices and falling profits, which they attributed to the return of French and English ships to the Mediterranean after the Napoleonic Wars. ${ }^{17}$ Their ranks included peddlers, shipping agents, merchant clerks, and others who had failed in the competitive world of the merchant diaspora. The Etaireia did not draw heavily from established and prosperous merchants whose wealth set them apart from traders experiencing economic reverses and who were reluctant to join a political conspiracy that could trigger Ottoman reprisals against their successful commercial activity in the Levant.

This pattern of Etaireia membership generally prevailed in Russia. Most Greeks who joined were recruited in Odessa after Alexandros Ypsēlantēs assumed leadership of the society in 1820. The prestige of his Phanariot name and his position as aide-de-camp of the tsar lent credence to widespread but false rumors that the tsarist government endorsed the Philike Etaireia and Greek liberation. While a few moderately successful merchants joined the society, most Greek etairists in Russia ( 85.5 percent) were struggling petty traders and clerks who had little to lose in supporting an uprising against Ottoman rule. ${ }^{18}$ Ypsēlantēs was patronized financially by a handful of established merchants in Moscow and Odessa but did not receive the amount of contributions he might have expected from Greek commercial wealth in Russia. The sparse donations he received from Inglezēs and other leading merchants in Odessa prompted his scorn. In a letter to Emmanouēl Xanthos, a founder of the society, Ypsēlantēs noted that the leading merchants sympathized with his plans but did not open their purse strings. Indeed, they were misers who "could donate five hundred thousand if they had convictions. This good cause will happen even without them." ${ }^{19}$ The wealthy merchants in this stratified Odessan Greek society feared, with prophetic justice, that a revolt would provoke an eastern crisis disrupting their flourishing trade in the Black Sea and Mediterranean. This sense of restraint and prudence was even more understandable in the case of Inglezēs, who was mayor of Odessa when the Philikē Etaireia was trying to recruit new members there.

After the outbreak of the Ypsēlantēs insurrection in Moldavia, the Greeks of Russia, and Russian society in general, promoted Greek independence in various ways. Because of its Greek community and its proximity to the Greek world, Odessa became a natural center of philhellenic activity, described by the exiled Aleksandr Pushkin. Inglezēs and other prominent merchants collected donations, arms, and supplies for Ypsēlantēs's beleaguered forces confronting Ottoman regular troops and reprisals. Ypsēlantēs acknowledged this assistance in a letter of March (23 March n.s.) to Inglezēs, calling him a "benefactor of the fatherland and the genos" for his efforts to raise support. ${ }^{20}$

17. The society's founders were Emannouēl Xanthos, a clerk in a firm that was out of business, Nikolaos Skouphas, an artisan who lost property because of bankruptcy, and Athanasios Tsakaloff, a clerk in a shipping company. George D. Frangos, "The Philike Etaireia, 1814-1821: A Social and Historical Analysis" (Ph.D. diss., Columbia University, 1971), discusses in great detail the social composition of the society.

18. Ibid., 136-139, and Arsh, Eteristskoe dvizhenie v Rossii, 167-296. On the Ypsēlantēs family in Russia see Arsh, "Ipsilanti v Rossii," Voprosy istorii, no. 3 (1985): 88-101, which also appeared in English in Balkan Studies, no. 1 (1985):73-90. Phanariots were prosperous aristocratic Greeks named after the Phanar, or lighthouse, district of Constantinople where many of them lived.

19. Arsh, Eteristskoe dvizhenie v Rossii, 259-261.

20. Ibid., 300-304, 333-346, on the patriotic activity of Greeks in Russia after the Ypsēlantēs uprising. On Russian philhellenism see Theophilus C. Prousis, "Russian Cultural Response to the Greek War of Independence (1821-1830)" (Ph.D. diss. University of Minnesota, 1982), and on Pushkin see the recent 
Inglezēs also collected Greek aid organized by Russian state and church officials. The relief project, an expression of Russian religious sympathy for Orthodox brethren, was prompted by Ottoman persecution of the Greek church, including the execution of Ecumenical Patriarch Grēgorios $\mathrm{V}$, and by the arrival in Odessa and Bessarabia of refugees fleeing Ottoman reprisals in Constantinople and the Danubian principalities. Their need for emergency shelter, food, and medical treatment drew the attention of regional and central authorities and became the impetus for a relief effort organized by Aleksandr N. Golitsyn, minister of public education and ecclesiastical affairs who sponsored many charitable works during his public service career. Golitsyn organized a second relief drive after the massacre at Chios in April 1822 left most of that island's population dead, displaced, or enslaved. Immortalized in Eugène Delacroix's "Scenes from the Massacre of Chios," this event aroused a Russian campaign to raise funds to ransom Greeks in Ottoman captivity. Although the tsarist regime condemned the Greek revolt as a threat to the Metternichean order of legitimacy, it endorsed Greek relief as a means to uphold Russia's traditional protection of co-religionists. Archival records amply demonstrate that a broad crosssection of society, from the imperial family to parish priests and peasants, contributed because of the religious bond with Orthodox Christians of the Greek east. ${ }^{21}$

The Greeks of Russia supported the relief projects by collecting and donating funds. For Inglezēs and other prominent Greeks the relief effort was a natural extension of their civic activism and sense of Greek identity. Urged by Golitsyn to participate because of his "distinguished merit" in previous public service, Inglezès became treasurer of the Odessa assistance committee that distributed aid to refugees. His methodical records of committee revenues and expenditures document the concrete assistance rendered by the committee during its existence from 1821 to 1831 . Inglezēs's elaborate record keeping won him praise from regional and central authorities. In early June 1822 Golitsyn wrote to Inglezēs that Tsar Alexander I was grateful for the committee's "diligence, righteousness, and good sense" in dispensing funds. The governorgeneral of Novorossiia, Mikhail S. Vorontsov, a major architect of that region's growth, wrote to Inglezēs in July 1826 and noted Tsar Nicholas I's approval of the committee's continued work on behalf of the refugees and the well-being of Odessa. ${ }^{22}$ Letters of appreciation from officials like Golitsyn were more or less pro forma to all who participated in Greek relief, but the efforts of Inglezēs and his committee were particularly crucial because of the large influx of refugees in Odessa.

Golitsyn asked Inglezēs to collect ransoms for Greek prisoners of the Ottoman government. In his letter of December 1822, Golitsyn described this new endeavor as another opportunity for Inglezēs to demonstrate his civic and humanitarian spirit: "where faith summons and humanity calls, your heart will inspire you to continue assisting your compatriots and thus gain an eternal reward." ${ }^{23}$ The Greek cleric and scholar Konstantinos Oikonomos also appealed to Inglezēs in

work of Ia. L. Levkovich, "Tri pis'ma Pushkina o Grecheskoi revoliutsii 1821 goda," Vremennik Pushkinskoi komissii, no. 21 (1987): 16-23. Ypsēlantēs's letter is in GAOO, d. 1, 1. 15.

21. Greek relief projects are treated in Theophilus C. Prousis, "Russian Philorthodox Relief during the Greek War of Independence," Modern Greek Studies Yearbook 1 (1985):31 -62, and in G. M. Piatigorskii, "Deiatel'nost' Odesskoi grecheskoi vspomogatel'noi komissii v 1821-1831 gg. (Po materialam Gosudarstvennogo arkhiva Odesskoi Obl.)," Balkanskie issledovaniia 8 (1982): 135-152.

22. GAOO, d. 14, "Ob Odesskoi grecheskoi vspomogatel'noi komissii," 1. 1-1a. In addition to his participation in Greek relief efforts, Inglezēs served on the initial staff of the office of public assistance (1823-1825). See d. 6, "O deiatel'nosti v Odesskoi prikaze obshchestvennogo prizreniia," 1. 1-2a. Copies of Inglezēs's records are located in GAOO, f. 1, op. 200, d. 72, 1. 344-390, and in the Central State Historical Archive, Lenningrad (TsGIA), f. 797, op. 2, d. 6395, 1. 125-131, 146-152; d. 6450, 1. 4-12, 29-35, 44-52, 69-72a, 91-96, 118-126; and d. 6520, 1. 138-144. The distribution process of the committee and the amounts of assistance issued to refugees are covered in Prousis, "Russian Philorthodox Relief," and Piatigorskii, "Deiatel'nost'." Golitsyn's letter is in GAOO, f. 268, op. 1, d. 14, 1. 2-2a, and Vorontsov's is in 1. 8. See Herlihy, Odessa, 76-82, 116-137, on the policies of Vorontsov in Novorossiia.

23. GAOO, f. 268, op. 1, d. 14, 1. 4-4a. 
religious and patriotic terms, underscoring that "faith and fatherland" were at stake and calling Inglezēs "a friend and fellow countryman." ${ }^{24}$ Inglezēs donated one thousand rubles to the ransom drive and collected additional funds from local Greeks. ${ }^{25}$

Inglezēs also organized support for the new Greek government of President Iōannēs Kapodistrias. During a visit to St. Petersburg in 1827, Kapodistrias wrote to prominent Greeks in Moscow and Odessa asking for their financial help. His letter to Inglezēs, couched in religious and patriotic terms, stressed the precarious status and strained resources of his government. Inglezēs collected donations from local Greeks and notified trade associates on the Ionian island of Zante to loan an undisclosed amount, assistance that Kapodistrias acknowledged in his correspondence. For his philhellenic activity during the Greek War of Independence, Inglezēs received the Gold Cross of the Order of the Savior from King Othon in $1844 .{ }^{26}$

Funds raised by the Greek communities of Russia were insignificant compared to the large and sustained relief support from Russian society, church, and government. Personal relief contributions by wealthy Greeks like Inglezēs (1,000 rubles) and Zoēs Zōsimas (2,000 rubles) were surpassed by contributions from leading Russian nobles like Anna A. Orlov-Chesmenskaia (8,000 rubles), Dmitrii N. Sheremetev (7,000 rubles), and Aleksei B. Kurakin (3,000 rubles). Reversals in Mediterranean commerce during the Greek war kept the Greek donations down. The sultan, suspecting Russian machination in the Greek revolt, confiscated Russian grain cargoes and closed the straits to Greek merchant ships and to all vessels flying the Russian flag. Some Greeks, such as Nikolaos Patsimadēs who collected only 1,620 rubles from Moscow Greeks, attributed meager donations to falling trade revenues that compelled individuals "generally known for their compassion" to restrict relief support. ${ }^{27}$

The setback in the Black Sea grain trade, greatly aggravated during the Russo-Turkish War of 1828-1829, alarmed established traders. In a memorandum written right after the conflict, Inglezēs registered concern about the precarious nature of Mediterranean commerce. ${ }^{28} \mathrm{He}$ noted that, with the start of peace negotiations, the sultan would soon restore free navigation and foreign merchants would again trade with Novorossiia. Russia's interests (and his own) were served by resuming grain exports before the ratification of the peace treaty. With the approach of fall, Russian merchants had to begin operations as quickly as possible because of the four-month commercial break during winter. If the reopening of the grain trade were postponed until the spring or summer of 1830, European merchants would turn to Egypt or other grain sources in the Levant. Although it remains unclear what, if any, influence this memorandum had on the speedy recovery of the grain trade, Inglezës's thoughts reflected his concern for the continued development of Odessa as the strategic center of the Mediterranean-Black Sea commercial network.

Inglezës's memorandum was written during his most active period of public service. He again combatted plague during the epidemic of 1829-1830. Appointed commissioner of health by Vorontsov, Inglezēs worked very hard. Vorontsov wrote to Inglezēs, "I consider it my duty to say that without your vigorous assistance it would not have been possible to achieve the success which crowned our joint efforts and saved the city from a terrible calamity." Vorontsov also

24. Ibid., d. 1, 1. 34-35. During ten years in Russia (1821-1831), Oikonomos published several sermons and scholarly works and promoted the Greek cause in the context of Greek-Russian religious ties. His career in Russia is similar to that of another Greek cleric described in Stephen K. Batalden, Catherine II's Greek Prelate: Eugenios Voulgaris in Russia, 1771-1806, East European Monographs (New York: Columbia University Press, 1982).

25. GAOO, d. 14, 1. 5-6, and TsGIA, f. 797, op. 2, d. 6449, 1. 1-192. Inglezẽs and fellow merchants Alexandros Koumbarēs and Alexandros Mavros organized the ransom collection in Odessa, one of numerous Greek communities in Russia that participated in the ransom drive.

26. Elenē Koukkou, Iōannès Kapodistrias. O anthrōpos-o diplömatēs (1800-1828), 2nd. ed. (Athens, 1984), 218-225. GAOO, d. 1, 1. 21-25, 26-27a; Nekrolog, 203-204.

27. TsGIA, f. 797, op. 2, d. 6484, 1. 13-18a; d. 6504, 1. 1-26; d. 6506, 1. 1-21; d. 6395, 1. 127; d. $6517,1.14-16$.

28. GAOO, d. 8, "Mnenie o torgovlykh perspektivakh po vyvozu khleba za-granitsu iz nashikh portov posle voiny," 1. 1-1a. 
conveyed the gratitude of Tsar Nicholas I for Inglezēs's humanitarian work in fighting the plague. $^{29}$

During the cholera outbreak of 1830, Vorontsov appointed Inglezēs to a commission to prevent the spread of the disease. The governor-general believed, based on previous "outstanding zeal for useful service and for the common good," that Inglezēs would succeed in this new effort. In 1837 Vorontsov again called on Inglezēs to help fight the plague. For his work during this outbreak, Inglezēs received a gold medal from the tsar. ${ }^{30}$ His activity against plague and cholera also earned Inglezēs the lasting gratitude of Odessa's inhabitants and officials.

In 1833 a poor harvest threatened Odessa's food supply and raised the possibility of famine. Vorontsov urged local merchants to procure grain from Bessarabia and he notified police and quarantine officials in Bessarabian towns that their assistance would be needed. Inglezēs's involvement was again solicited by the governor-general, who cited his past service record and referred to him as "one of the most solid and respected men we have here." ${ }^{31}$ Inglezēs and other merchants contributed to the success of this project by shipping grain to Odessa and, thus, helped avert the worst consequences of the bad harvest. In his letter of appreciation to Inglezēs, Vorontsov provided compensation for his expenses and again conveyed the tsar's praise for his humanitarian work. ${ }^{32}$

Inglezēs was also active in the attempt to pave Odessa's streets. The absence of paving had given credence to Pushkin's line in Evgenii Onegin, "I lived then in dusty Odessa." In 1827 local merchants and sea captains had been urged to procure foreign stone, instead of local limestone with its soft composition, for street paving. ${ }^{33}$ Upon conclusion of the Russo-Turkish War in 1829 , Inglezēs, fully aware of the commercial advantages of paved streets and stone bridges for Odessa, became involved in this endeavor. His correspondence indicates that merchant associates in Livorno, then a prominent port in the Greek commercial networks, began purchasing the required stone and that he expected equally satisfactory reports from merchant contacts in the archipelago. Inglezēs pledged, "as a citizen of Odessa," full support for this project that would benefit the city and his own firm. ${ }^{34}$

The Inglezēs archive contains many documents regarding this project, such as tsarist authorization (1832) for his travel to Constantinople, Greece, and the Ionians to procure stone and an official record (1833) certifying his return from abroad and his safe passage through quarantine. ${ }^{35}$ Little came of this early attempt to pave Odessa's streets; mud and dust continued to hinder efficient local transport. By 1861, the city was only partially paved, and not until 1895 were streets in the center of town and in some of the outlying areas paved. ${ }^{36}$

When Inglezēs died in 1844, he had carried to Russia the Inglezēs family tradition of commercial success and civic activism. He had earned the esteem of Odessa's citizens and officials alike for his participation in municipal affairs, particularly his steadfast humanitarian work. A cross-section of the city's population attended his funeral at the Holy Trinity Greek Orthodox Church. Inglezēs held a prominent place in the stratified Odessan Greek society. His experience illuminates both the common pattern of assimilation, public service, and retention of ethnic identity among wealthy and established Greek merchants of the diaspora and the durability of historical bonds between Russia and the Greek east.

29. Ibid., d. 15, "O merakh prekrashchenii kholery i chumy v Odesse," 1. 3-3a.

30. Ibid., 1. 5-5a., 1. 7, 1. 8-10.

31. Ibid., d. 10, "O zakupke khleba dlia pomoshchi bedstuiushchim ot urozhnaia," 1. 1-1a, 6-7.

32. Ibid., 1. 2-2a.

33. Herlihy, Odessa, 131.

34. GAOO, d. 11, "O zamoshchenii ulits Odessy," 1. 1-5.

35. Ibid., d. 16, "O poezdke v Konstantinopol' i Gretsiiu," 1. 2-8.

36. Herlihy, Odessa, 132, 237. 